\title{
Correlation of Ankle Brachial Index (ABI) To The Risk of Diabetic Wound Ondiabetes Mellitus Type 2
}

Sri Yanti ${ }^{1}$ and Murgiyati ${ }^{2}$

${ }^{1}$ Nursing Program, STIKes Payung Negeri Pekanbaru, Indonesia

${ }^{2}$ Santa Maria Hospital, Pekanbaru, Indonesia

\section{Abstract}

Diabetes mellitus is a chronic disease caused by inherited and or acquired deficiency inproduction of insulin by the pancreas, or by the ineffectiveness of the insulin produced. Such a deficiency result in increased concetrations of glucosa in the blood, which in turn damage blood vessel. Peripheral arterial disease (PAD) is a complication of diabetes that happens when blood vessels in the legs become blocked or narrowed due to fat deposits. Diabetic patient with PAD have a high risk to get diabetic wound caused high concetrations of blood. Simple test used to document PAD is measure of the ankle brachial index (ABI). ABI compares the systolic blood pressures of the ankle or legs with brachial or arms to give a ratio that can suggest various severity of PAD. This study aimed to determine the relationship between the $A B I$ and diabetes type 2 patient's wound risk of type 2 in Santa Maria Hospital Pekanbaru. These study was quantitative research with cross sectional approach with 55 respondents. The study was conducted in April 15 to May 20 2018. The study measured the ABI and anamnese signs and symptoms of PAD. The results of this study showed that there was a relationship between the $\mathrm{ABI}$ and wound risk in diabetic type 2 patient in Santa Maria Hospital Pekanbaru $(p=0,000)$. This study recommended healthcare service do the $A B I$ measurement for diabetes patients to early detection PAD and prevent the diabetic wound.

Keywords: $A B I$, diabetic type 2, wound risk

\section{Introduction}

Diabetes Mellitus (DM)is a group of metabolic diseases characterized by hyperglycemia resulting from defects in insulin secretion, insulin action, or both. Diabetes Mellitus is classified into 4 types namely DM type1 (absolute insulin deficiency), DM type 2 (noninsulin-dependent diabetes), gestational DM and other specific types of DM. Non-insulin-dependent diabetes (DM type 2) is the most common form of diabetes, which accounts for 85 - 95\% of those aged $40-59$ years old. People with diabetes 
are highly vulnerable of having wound, especially at feet. The wound in this Diabetes Mellitus is chronic and usually hard to cure.A study in United States shown that $75 \%$ of diabetic people get health problem on their feet while $44 \%$ of them must get medical treatment $[1,5,19]$.

Diabetes Mellitus is a chronic disease which fastens the atherosclerosis and according to some researches, is the main cause of PeripheralArterialDisease(P.A.D). Peripheral Arterial Disease is a disease in which plaque builds up in the arteries that carry blood to your head, organs, and limbs. Therefore theperipheral blood perfusion will be limited. This is also one of the causes of diabetic wounds on the patients with diabetes Mellitus type 2. Peripheral arteries that are often disrupted are the tibial artery and peroneal artery or fibular artery, especially the area between the knee and leg joint $[3,16]$.

Some researches found that a non-invasive examination to evaluate P.A.D and recommended for the patients of diabetes mellitus older than 50 years old is known as Ankle Brachial Index (A.B.I) test. The normal score of A.B.I is $0.9-1.3$, in which the value lower than 0.9 is categorized as abnormal and when the score is higher than 1.3is the sign of classification on the blood vessels, therefore the result of A.B.I test can be used to diagnose P.A.D. The lower A.B.I score means higher risk of vascular disease [8, 12]. At that time, the patients usually have claudication complaints (pain in the extremities). On the other hand, when the $A B I$ index is lower than 0.5 , the patients usually have claudication when they take rest. As of 2015, an estimated 415 million people had diabetes worldwide,and there will be 642 million people with diabetes in 2040. The numbers of diabetes patients in Indonesia is the seventh with 10.2 million people and will significantly increase into 21.3 million in 2040 . The data recorded that there are 422 million diabetes people in 2016 and 1.5 million people die due to diabetes mellitus[7, 18, 19]. Santa Maria Hospital aa one of the biggest hospitals in Pekanbaru also recorded the inceasing number of diabetes mellitus patients both inpatiens and outpatients.

Based on the interview with the nursing management of Santa Maria Hospital, it can be concluded thatthere is no standard procedure of $A B I$ test for patient of diabetes mellitus and in general the nurses of the hospital do not know how to conduct the $A B I$ test. In fact, the knowledge on how assesing the $A B I$ in order to detect the PAD earlier as one of a risk factor of diabetic wound is important as the number of diabetes mellitus patients increased. Based on that preliminary observation, the researcher is interested in conducting a research on the correlation of Ankle Brachial Index to the risk of deabetic wound on Diabetes Mellitus type 2 patients at Santa Maria Hospital Pekanbaru. 

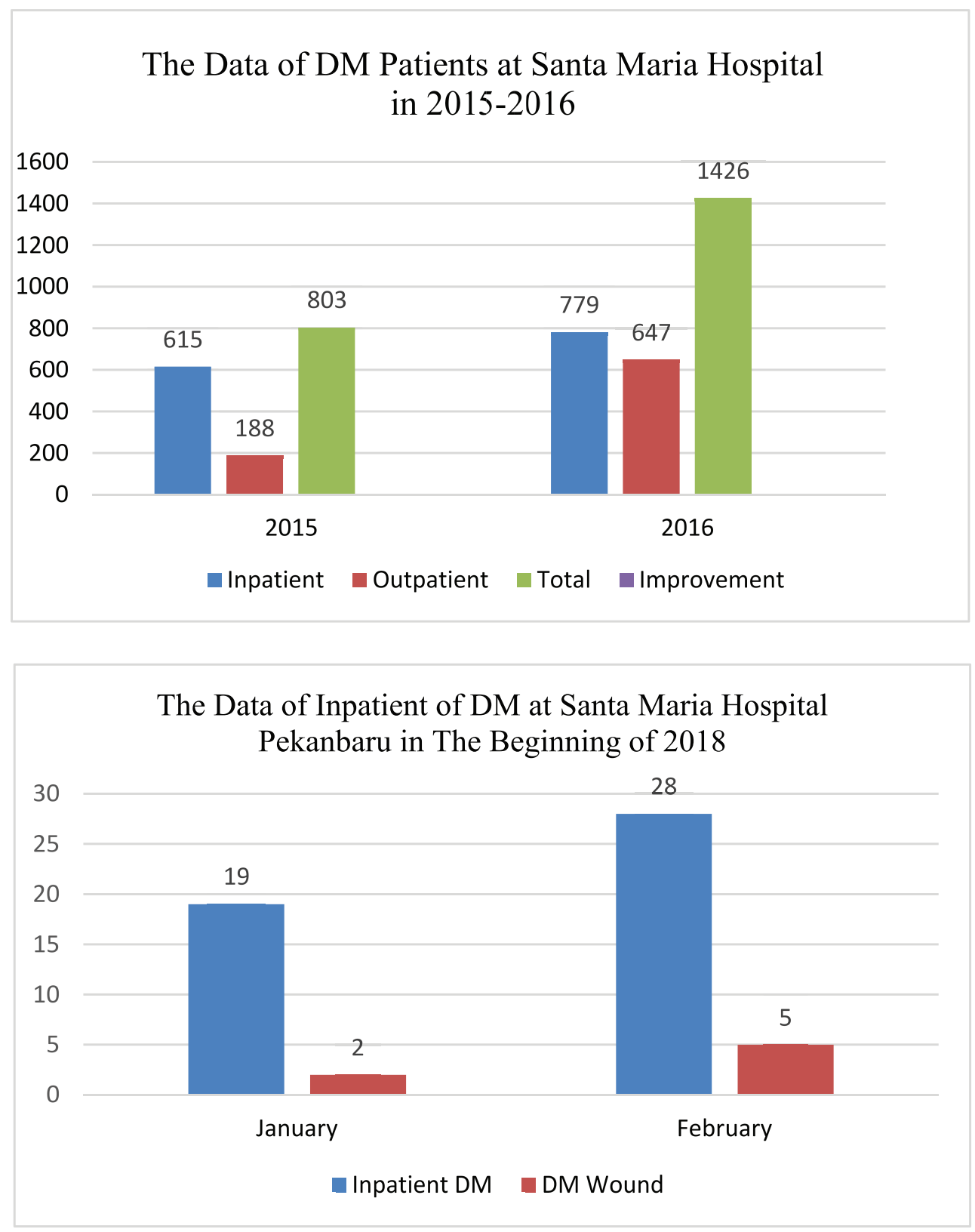

Figure 1: Sources: The Data of Medical Records at Santa Maria Hospital Pekanbaru.

\section{Methods and Equipment}

This is a quantitative research using cross sectional design. The data collected by observation onmeasuring of systolic blood pressure on both extremities in the brachial and ankle areas of the inpatiens of Diabetes Mellitus type 2 and conducting anamnesa on the symptoms of PAD at Santa Maria Hospital. The sampling technique is using consecutive sampling method. The inclusion criteria is the diabetes mellitus patients with no diabetic wound, while the exclusion criteria is the diabetes patients with extrimity edema, have 
D.V.T disease and breathless that can not lay down in 5-10 minutes. The research instrument is using the vascular doppler $5 \mathrm{Mhz}$. The measurement was carried outon both ankles and brachials. The results of $\mathrm{ABI}$ measurements were that blood pressure in the cystole ankle was divided into systole brachial blood pressure. Diabetic patientshave a risk of diabetic injury if the $A B I$ value is abnormal and there is one symptom of PAD. Patients who are not at risk of experiencing ulcers if the value of $A B I$ isnormal and no signs of PAD were found. The symptoms of PAD are claudication, resting time pain, history of scarred wounds, dorsalis pedis pulse or tibial penosterior were not palpable or weak, legs looked pale, and cool feet. Data analysis on this research used the Chi Square test to test the level of statistical significance between the value of the brachial index and the risk of diabetes wound in patients with type 2 diabetes mellitus.

\section{Result}

Based on the results of the research, it was found that most of type 2 Diabetes Mellitus patients were suffered by patients aged 45-54 years and aged 55-64 years respectively as $29.1 \%$. The third Diabetes Mellituspatients based on the results of the research were 65-74 years old as much as $18.2 \%$. patients with an age range of 15-24 years and 25-34 years old are the smallest number of DM patients, which are $1.8 \%$. This is consistent with the International Diabetes Federation (IDF) report that the number of Diabetes Mellitus patients increased at the age of 19-74 years and the age group 70-74 years had a higher incidence of $19.4 \%$ followed by the age group 55-59 years (Huang et al., 2015). According to WHO (2016) as the age increased,the ability of tissues to take blood glucose decreases and usually happened on patients over the age of 40 years.

There were 55 respondents with a total of female respondents was $52.7 \%$ and men $47.3 \%$, female and male ratios 1.1:1. Other research conductedby Osei et al ((2013) in America found the ratio of women with diabetes mellitus and men was 2:1, while research by Choi et al (2014) in South Korea found the ratio diabetes mellitus onmale to female 2:1. Based on the educational background of patients, most of patients with type 2 diabetes mellitusat Santa Maria Hospital were the respondents with secondary education level, namely junior high school and high school that was as much as $43.6 \%$. Respondents with lower education as much as $32.7 \%$ and higher education as much as $23.7 \%$. In the case of diabetes mellitus patients education is not a risk factor, but education will be useful when someone has been affected by diabetes mellitus. The educational background will help the patient in managing and implementing ways to prevent DM complications and maintain blood sugar stability. Most of the patients have the type 2 diabetes mellotus for 
$1-5$ years, which is $38.2 \%$ and then $<1$ year is $29.1 \%$. From these results we can conclude that many patients newly diagnosed with type 2 diabetes mellitus. This is in accordance with what was revealed by the International Diabetes Ferderation (IDF) in 2015 world DM sufferers continue to increase every year, 2015 amounting to 415 million people and estimated to increase to around 642 million people with DM in 2040. The World Health Organization (WHO, 2017) stated that the number of DM patients in 2017 is 422 million. IDF in 2015 explained the main complications of diabetes are attacking organs such as the eyes, oral health, heart, kidneys, nervous system and causing diabetic wounds. From the results of the study patients with type 2 DM in Santa Maria Hospital had the most comorbidities, hypertension as much as $16.7 \%$, stroke infarction $12.7 \%$ and TB 9.09\%.According to $\mathrm{WHO}$ the diagnosis of DM patients if the patient experiences classic DM symptoms namely polyuri, poliphagi, polydispi and has GDS> 200 mg / dl or GDP> $126 \mathrm{mg} / \mathrm{dl}$, or GDPP> $200 \mathrm{mg} / \mathrm{dl}$. From the results of the study of DM patients who measured ABI GDS measurement results> $200 \mathrm{mg} / \mathrm{dl}$ as much as $54.5 \%$ and the rest had GDS $<200 \mathrm{mg} / \mathrm{dl}$ as much as $45.5 \%$. Based on the results of the research on55 respondents, $70.9 \%$ of the results of normal $A B I$ measurements were 0.911 .3 , the results of $A B I$ with mild occlusion were $0.7-0.9$ as much as $23.6 \%$ and the remaining $5.5 \% \mathrm{ABI}$ values $>1.3$ or experiencing blood vessel calcification. Based on male sex respondents as many as 26 patients who had normal $A B I 76.95$, mild occlusion 19.2\% and vascular calcification 3.8\%, while female respondents as many as 29 patients had normal ABI $65.5 \%$, mild $A B I$ occlusion $27.6 \%$ and $A B I$ with vascular calcification $6.9 \%$.

Based on the results above, it can be seen that women have more abnormal $A B I$ than men, both in mild occlusion and in blood vessel calcification. The comparison is 1.3:1. The research conducted by Pratomo (2014) in Lampung, concluded of 98 type 2 DM patients with $22.5 \% \mathrm{ABI}$ abnormalities also found that the abnormal $A B I$ ratio of Bordeline $A B I$ in Type 2 DM patients between women and men was 1.3:1 Najla et al. research In 2016 in Pontianak, the results of 80 respondents found $A b i$ abnormal value was higher than the normal $A B I$, which was as much as $51.25 \%$ while the normal one was $48.75 \%$. (After this is lot of graphics) 
The Respondents Characteristics Based on The Age of DM Patients at Santa Maria Hospital in 2018

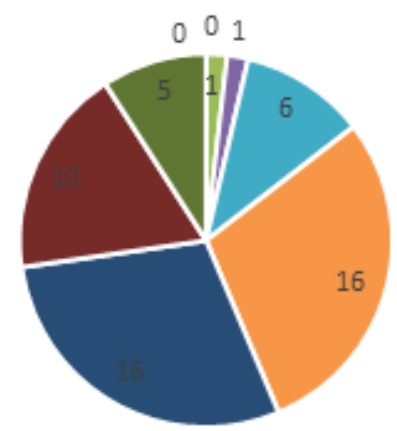

$$
\begin{aligned}
& \text { - 15-24 years old } \\
& =25-34 \text { years old } \\
& =35-44 \text { years old } \\
& =45-54 \text { years old } \\
& -55-64 \text { years old } \\
& =65-74 \text { years old } \\
& =>74 \text { years old }
\end{aligned}
$$

The Respondents Characteristics Based on Gender of DM Patients at Santa Maria Hospital Pekanbaru in 2018

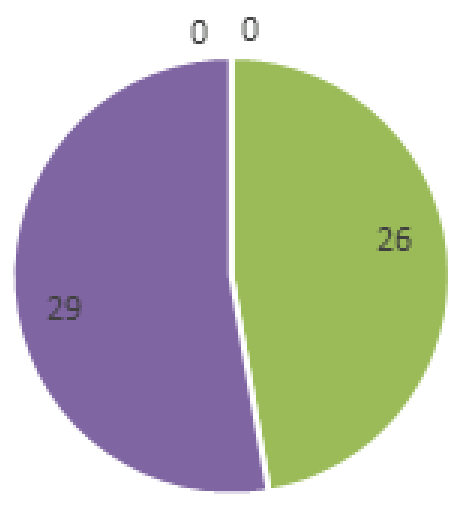

$$
\begin{aligned}
& \text { - Male } \\
& \text { - Female }
\end{aligned}
$$

Respondents Characteristics Based on DM Patients'

Educational Background at Santa Maria Hospital

艺 Pekanbaru in 2018
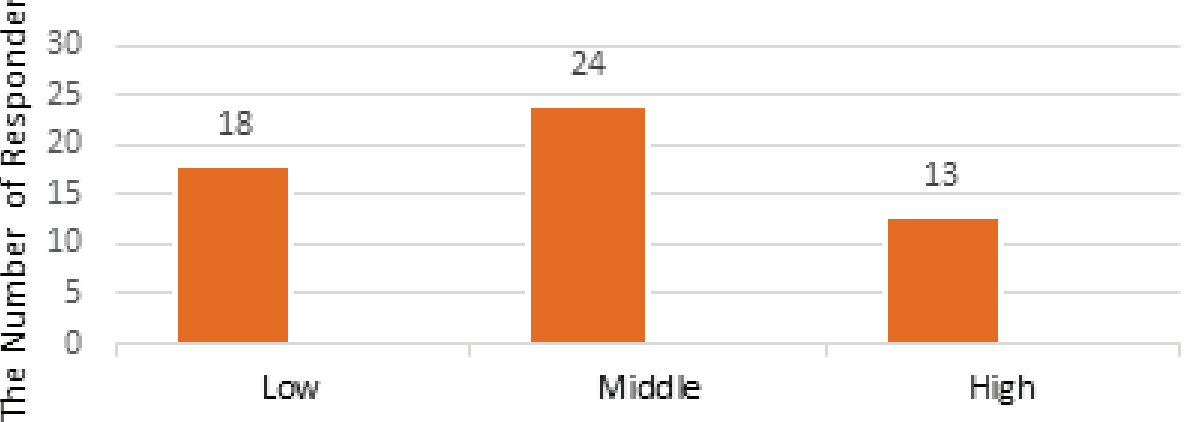

Middle

High

Educational Background 
The Respondents Characteristics Based on The Length of Time Suffering from DM at at Santa Maria Hospital Pekanbaru in 2018

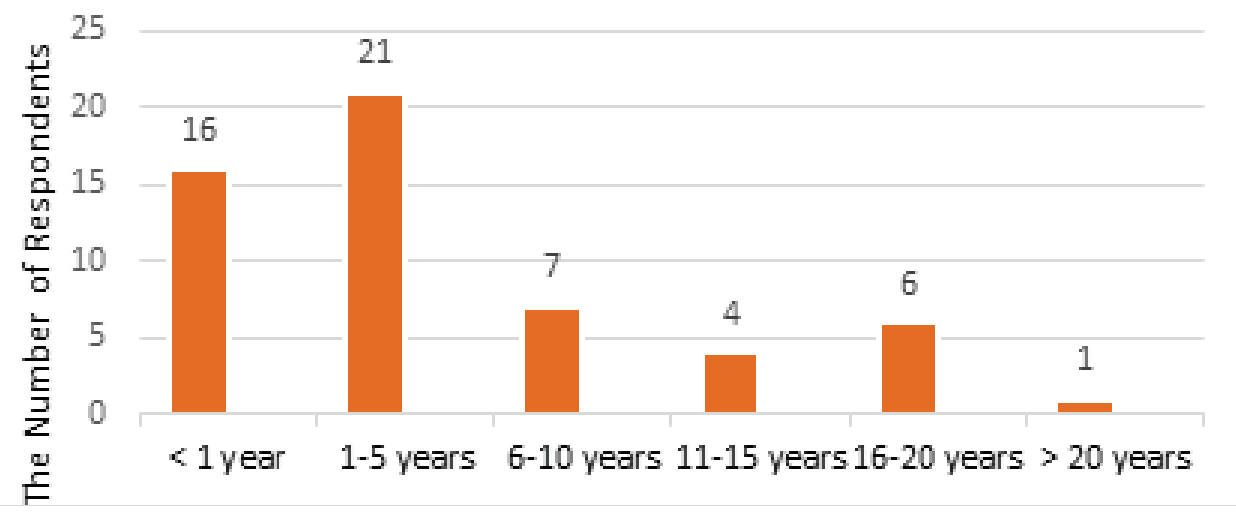

The Respondents' Characteristics Based on The Disease

Along With DM at Santa Maria Hospital Pekanbaru

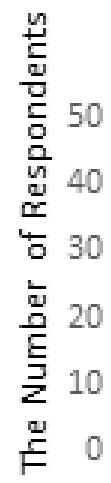
2018

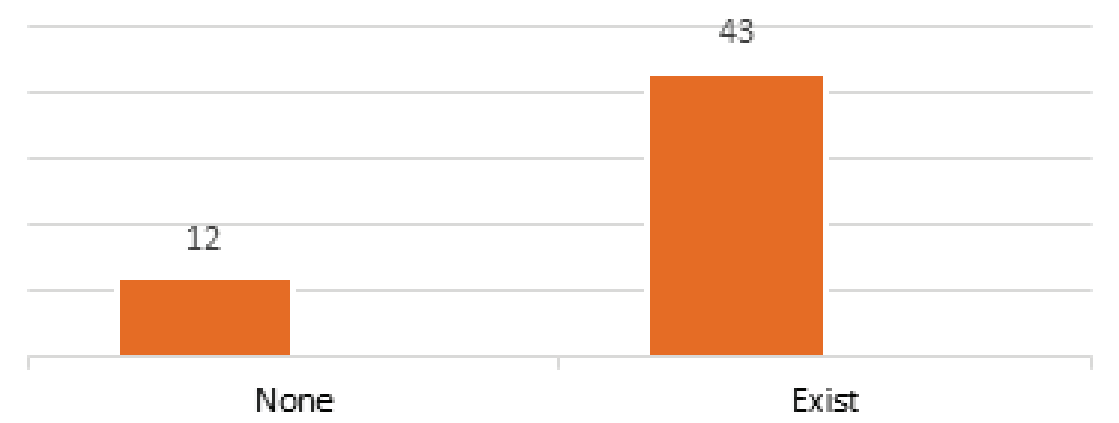

The Respondents Characteristics Based on The Length of Suffering from DM at Santa Maria Hospital

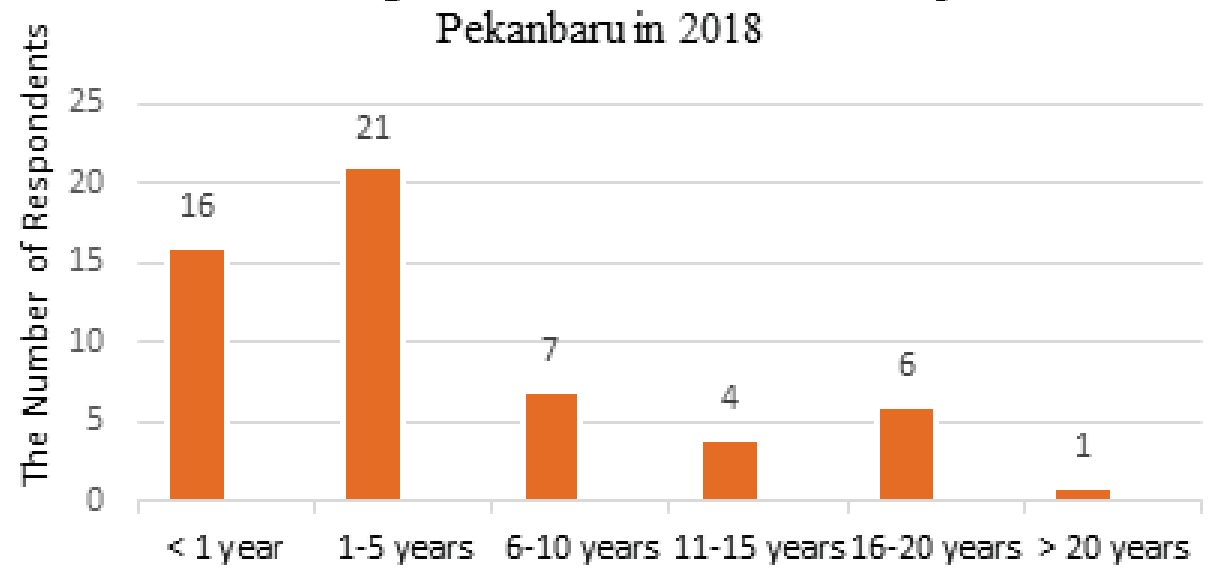




\section{The Respondents Characteristics Based on Blood Sugar Levels of DM Patients at Santa Maria Hospital Pekanbaru in 2018}

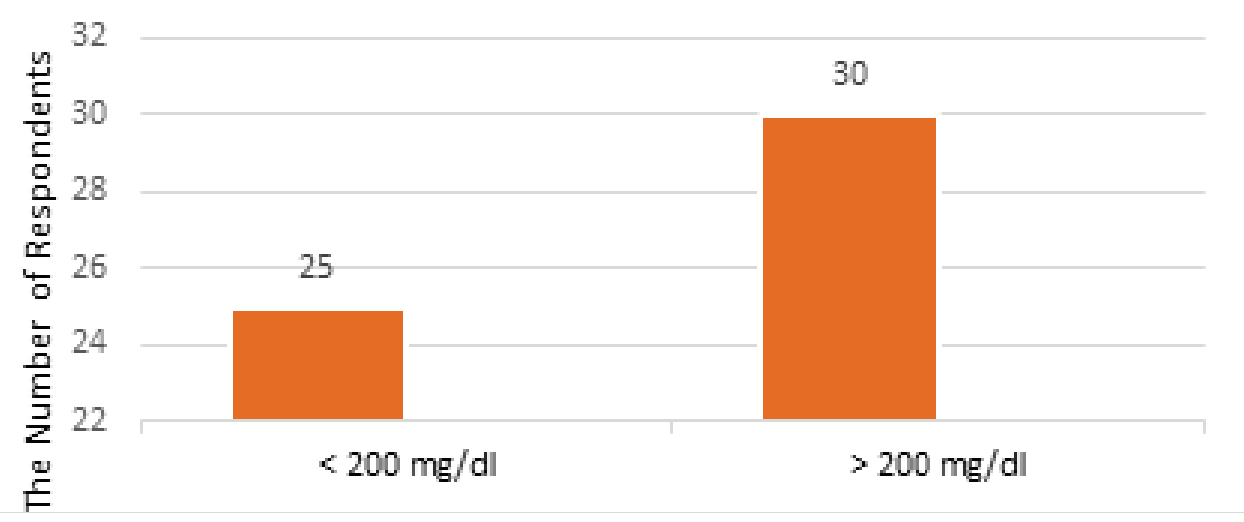

TABLE 1: Distribution of Respondents Based on ABI Value and Wound Risk of Type 2 DM Patients at Santa Maria Hospital.

\begin{tabular}{|l|c|c|c|c|}
\hline Wound Risks & $\begin{array}{c}\text { No } \\
\text { Symptoms } \\
\text { of PAD }\end{array}$ & $\begin{array}{c}\text { There is } \\
\text { Symptom } \\
\text { of PAD }\end{array}$ & Total & P value \\
\hline ABI Scores & $\begin{array}{c}35 \\
89.7 \%\end{array}$ & $\begin{array}{c}4 \\
10.3 \%\end{array}$ & $\begin{array}{c}39 \\
100 \%\end{array}$ & $\mathbf{0 . 0 0 0}$ \\
\hline ABI Normal (0.91-1.3) & 0 & 13 & 13 \\
\hline Mild Occlusion (0.7-0.9) & $0 \%$ & $100 \%$ & $100 \%$ \\
\hline Blood vessel classification (ABI > 1.3) & 0 & 3 & 3 \\
\hline Total & $0 \%$ & $100 \%$ & $100 \%$ & \\
\hline Source: Results of the 2018 study & $\mathbf{3 5}$ & $\mathbf{2 0}$ & $\mathbf{5 5}$ \\
\hline
\end{tabular}

Based on the results of the Chi Square bivariate analysis with Pearson Chi Sguare is obtained $(P=0,000<\alpha: 0,05)$ that $H O$ is rejected, it can be concluded that there is a significant relationship between $A B I$ and the risk of diabetic wound. Based on the definition of operational risk of wound is when patients with type $2 \mathrm{DM}$ with $A B I$ values are $A B I<0.9$ and $A B I>1.3$ and have one symptom of peripheral arterial disease (PAD). Symptoms of PAD according to the American Association Heart ( $A H A)$ are cheating, pain at rest, history of injury which is difficult to heal, nadidorsalis pedis or posterior tibialist is not palpable or weak, pale and cold on the legs [3]. According to the research of the United Kingdom Prospective Diabetes Study (UKPDS) DMtype 2 patients are at risk of developing PAD compared to general patients. Every $1 \%$ increase in $\mathrm{HbA} 1 \mathrm{C}$, there is a $28 \%$ risk of experiencing PAD. The results of the study on 55 respondents, $70.9 \%$ were 
not at risk of experiencing diabetic wounds and $29.1 \%$ of patients who had a risk of experiencing diabetic wounds [12].

\section{Conclusion}

Research on the correlation of $A B I$ to the risk of diabetic wounds in type $2 \mathrm{DM}$ patients at Santa Maria Pekanbaru Hospital can be concluded with the results of $A B I$ measurements from 55 respondents obtained results $70.9 \%$ of patients had normal $A B I$ values and $23.6 \%$ mild occlusion and the remaining $5.5 \%$ experienced calcification of blood vessels with $A B I$ values $>1.3$. The risk of diabetic wound is measured by two indicators, namely the $A B I$ value $<0.9$ and there is one or more PAD signs. The results showed that $70.9 \%$ were not at risk of developing diabetic wounds and $29.1 \%$ of patients who had a risk of developing diabetic wounds. Based on the Chi Square statistical test there is a significant correlation between the value of $A B I$ and the risk of injury in type $2 \mathrm{DM}$ patients at the Santa Maria Hospital in Pekanbaru with a P value $=0,000<0.05$.

Hospitals are expected to conduct $A B I$ measurements well as a standard procedure for diabetic patients to detect early symptoms of PAD and risk of diabetic wounds. For further research it is recommended to conduct research on ways or techniques to keep $A B I$ values within normal limits.

\section{Funding}

This research was supported by the researchers and Nurses of Santa Maria Hospital Pekanbaru Riau Indonesia.

\section{Acknowledgement}

The researcher would like to thank Payung Negeri Institute of Health and Santa Maria Hospital Pekanbaru for their contribution and support to the research. The researcher is also thankful to the reviewers who gave their valuable inputs to the manuscript and helped in completing the paper.

\section{Conflict of Interest}

The researcher has no conflict of interest to declare. 


\section{References}

[1] American Diabetes Association (ADA). (2017). Standards of Medical Care in Diabetes 2017.

[2] Choi dan Jeon SB.(2014). Predictive factors for successful limb salvage surgery in diabetic foot patients, 14:113. Retrieved from http://www.biomedcentral.com/ 1471\%0A2482/14/113.\%0A. Diakses 10 Juni 2017.

[3] Gerhard Herman, et.al. (2016). AHA/ACC Guideline on the Management of Patients With Lower Extremity Peripheral Artery Disease: Executive Summary: A Report of the American College of Cardiology/American Heart Association Task Force on Clinical Practice Guidelines.

[4] Journal of the American College of Cardiology, 69(11), 1465-1508. https://doi.org/10. 1016/j.jacc.2016.11.008

[5] Gitarja, W. S. (2008). Perawatan Luka Diabetes. (T. W. Publishing, Ed.) (Seri Peraw). Bogor: WOCARE INDONESIA.

[6] Huang, Y., Ogurtsova, K., Fernandes, R., Cavan, D., Makaroff, L. E., Shaw, J., \& Cho, N. H. (2015). IDF Diabetes Atlas Estimates for the Global Diabetes Prevalence of Adults Aged 18 to 99 years, (1671), 1671.

[7] International Diabetes Federation (IDF). (2011). IDF Diabetes Atlas Fifth edition. (online) http://www.idf.org/sites/default/ files/ EN_6E_Atlas_Full_pdf, diakses 30 Oktober 2017.

[8] Kirsner, M. F. (2010). The Standard of Care for Evaluation and Treadment of Diabetic Foot Ulcers.

[9] Osei D, Brechow A, Slesaczeck T, Münch D, Nanning T, Paetzold H, et al. (2013). Improving major amputation rates in the multicomplex diabetic foot patient focus on the severity of peripheral arterial disease;4(3):83-94.

[10] PERKENI. (2015). Pencegahan dan pengelolaan Diabetes Melitus Tipe 2 di Indonesia, (Online) http:labcito.co.id/wpcontent/upload/2015/03/RevisiFinal.pdf. diakses 30 Oktober2017.

[11] Potier, L., Khalil, C. A., Mohammedi, K., \& Roussel, R. (2011). Use and Utility of Ankle Brachial Index in Patients with Diabetes. European Journal of Vascular \& Endovascular Surgery, 41(1), 110-116. https://doi.org/10.1016/j.ejvs.2010.09.020

[12] Pratomo, I. B. (2014). Gambaran ABI Penderita DM tipe 2 di Puskesmas Kotabumi II Kabupaten Lampung Utara tahun 2014, 1-37.

[13] Rekam Medis. RS Santa Maria 2016. Pekanbaru. 
[14] Riset Kesehatan Dasar, (2013). Penelitian \& Pengembangan.(online).www.d epkes.go.id. Diakses 10 Agustus 2017.

[15] Standards of Medical Care in Diabetes (2017), American Diabetes Asosiation (ADA). 40( January).

[16] Resnick, H. E., Lindsay, R. S.,Mcdermott, M. M., Devereux, R. B., Jones, K. L., Fabsitz, R. R., \& Howard, B. V. (2014). Relationship of High and Low Ankle Brachial Index to AllCause and Cardiovascular Disease Mortality. https://doi.org/10.1161/01. CIR.0000112642.63927.54

[17] Standards of Medical Care in Diabetes (2017), American Diabetes Asosiation (ADA). 40( January).

[18] World Health Organization (WHO). (2016a). Diabetes Magazine is on the Rise 3.7, 1-2. (Januari 2016)

[19] World Health Organization (WHO). (2016). Global Report on Diabetes. www.who.int. Diakses 1 September 2017.

[20] Yuliani, F., Oenzil, F., \& Iryani, D. (2014). Artikel Penelitian Hubungan Berbagai Faktor Risiko Terhadap Kejadian Penyakit Jantung Koroner Pada Penderita Diabetes Melitus Tipe 2, 3(1), 37-40. 